University of Michigan Law School

University of Michigan Law School Scholarship Repository

Law \& Economics Working Papers

$11-15-2012$

\title{
SEC Investigations and Securities Class Actions: An Empirical Comparison
}

\author{
Stephen Choi \\ NYU Law School, stephen.choi@nyu.edu \\ Adam Pritchard \\ University of Michigan Law School, acplaw@umich.edu
}

Follow this and additional works at: https://repository.law.umich.edu/law_econ_current

Part of the Law and Economics Commons, and the Securities Law Commons

\section{Working Paper Citation}

Choi, Stephen and Pritchard, Adam, "SEC Investigations and Securities Class Actions: An Empirical Comparison" (2012). Law \& Economics Working Papers. 55.

https://repository.law.umich.edu/law_econ_current/55

This Article is brought to you for free and open access by University of Michigan Law School Scholarship Repository. It has been accepted for inclusion in Law \& Economics Working Papers by an authorized administrator of University of Michigan Law School Scholarship Repository. For more information, please contact mlaw.repository@umich.edu. 


\title{
SEC InVESTigations AND SeCURITIES Class ACtions: AN EMPIRICAL COMPARISON
}

\author{
Stephen J. Choi \& A.C. Pritchard*
}

Date: November 13, 2012

\begin{abstract}
We compare investigations by the SEC with securities fraud class action filings involving public companies. Using actions with both an SEC investigation and a class action as our baseline, we compare SEC-only investigations with class action-only lawsuits. We find evidence that the stock market reacts more negatively to the class actions relative to SEC investigations. We also find that institutional ownership and stock turnover decline more for class actions compared with SEC investigations. Lastly, the incidence and magnitude of settlements, as well as the incidence of top officer resignation, are greater for class actions relative to SEC investigations. This evidence is consistent with private class actions pursuing more egregious securities law violations than SEC investigations and imposing greater sanctions against companies. At least for the metrics employed here, our findings are consistent with the private enforcement providing at least as much deterrent value, if not more, than public enforcement.
\end{abstract}

\footnotetext{
* Murray and Kathleen Bring Professor of Law, New York University and Frances and George Skestos Professor of Law, University of Michigan, respectively. The authors thank Un Kyung Park as well as participants at a Fawley Lunch at the University of Michigan Law School for helpful comments on earlier drafts. We are particularly grateful to Cornerstone Research for assisting us with data on SEC investigations and enforcement actions used here.
} 


\section{Introduction}

Critics of securities class actions (e.g., Rose 2008)) commonly contrast those suits with enforcement actions brought by the SEC. According to those critics, the SEC is superior to plaintiffs' lawyers both in targeting defendants and securing sanctions against them. The SEC's purported superiority is claimed to stem from its incentive to pursue the public interest, rather than the profit motive that drives the plaintiffs' bar.

With respect to targeting, critics of securities class actions claim that the settlement dynamics of class actions encourage plaintiffs' lawyers to bring a high proportion of nonmeritorious suits. After the passage of the Private Securities Litigation Reform Act in 1995, typically half of all securities fraud class actions are dismissed. Notwithstanding this screening, the incidence of a substantial percentage of securities class actions producing small-scale settlements supports the argument that many settled suits would be unlikely to yield a plaintiff verdict if they were to go to trial. These small settlements suggest that asymmetric litigation costs lead defendant companies and their insurers to pay settlements that can arguably be called "nuisance value." If companies must pay substantial costs when they are unjustifiably targeted, the deterrent value of class actions is diluted.

With regard to sanctions, class action settlements are almost always paid by the company and its directors' \& officers (D\&O) insurance; the corporate officers responsible for the fraud rarely contribute. By contrast, SEC enforcement actions commonly lead to payments from the responsible officers; the SEC also has the authority to bar individuals from serving as directors and officers of public companies, a career death sentence for the individual subjected to a bar. 


\section{Choi and Pritchard:}

\section{SEC v. Class Actions}

Critics of class actions argue that the combination of more precise targeting of suits and more individual sanctions yields a stronger deterrent punch for SEC enforcement relative to class actions. (Bratton \& Wachter, 2011.) If this argument is correct, it follows that shifting to an enforcement model that focuses exclusively on government enforcement would yield a bigger deterrent impact for the marginal dollar spent on adjudicating fraud.

We think that critics contrasting securities class actions and SEC enforcement actions may be comparing apples to oranges. The comparisons ignore a critical institutional detail: SEC enforcement actions are brought only after the SEC has done a substantial investigation into the alleged wrongdoing. That investigation is aided by the SEC's subpoena power, which yields cooperation from defendants even when it is not explicitly invoked. By contrast, plaintiffs filing securities class actions are barred from seeking discovery from defendants while a motion to dismiss is pending. Motions to dismiss are filed in virtually every securities class action, so plaintiffs must bring their case almost exclusively on the basis of publicly available information. That relative dearth of information explains why those actions are frequently dismissed. Would the SEC's enforcement efforts look so effective if the agency were forced to rely exclusively on public information?

In this study, we attempt to shed light on the question of the relative merits of private and public anti-fraud enforcement in fostering deterrence. Instead of looking at SEC enforcement actions, we shift the focus to SEC investigations. Comparing SEC investigations with class actions involving public companies allows us to compare public and private enforcement on a more level playing field. Moreover, this comparison also better reflects the burdens faced by companies that are the targets of the two enforcers- 


\section{SEC v. Class Actions}

facing an SEC investigation can result in expenses equal if not exceeding the expenses of facing a class action filing. Defense costs for defending a company involved in an SEC investigation are substantial; often they are likely to be more significant than the costs to defend a class action through the motion to dismiss stage. Unlike SEC investigations, no discovery - the source of the greatest litigation expense and distraction - is available in a class action until after the motion to dismiss has been decided.

We use a number of metrics to compare SEC investigations and private class action filings. We employ an event study around the first public announcement of the underlying securities law violation and the first public announcement of an SEC investigation or class action filing. Given the need to prove loss causation and damages, we predict the class action will target larger stock price drops. We find that the market reacts significantly more negatively to announcements of securities law violations that lead to a stand-alone class action filing as opposed to a stand-alone SEC investigation.

We assess several measures that capture how the market views a company after an announcement of a potential securities law violation. We are interested in market perceptions of the level of information asymmetry, the reliability of management, and accuracy of disclosures. Our measures include changes in institutional ownership, analyst forecast dispersion, stock turnover, and the bid-ask spread. We find that when a company faces both an SEC investigation and class action filing there is significantly greater loss of market confidence relative to situations in which there is only an SEC investigation or a class action filing. Moreover, we also find no evidence that stand-alone class actions have weaker market indicia of disclosure unreliability than stand-alone SEC investigations. Indeed, two of our measures-decrease in institutional ownership and stock turnover- 


\section{SEC v. Class Actions}

show a stronger correlation with stand-alone class actions than with stand-alone SEC investigations.

We also assess the consequences for companies and their officers that flow from SEC investigations and class actions. For this analysis, we compare the monetary sanctions: civil penalties and settlements. We find that the combination of both an SEC investigation and a class action filing is more likely to produce a settlement than an investigation or class action filing standing alone. We also find stand-alone class actions are more likely to produce a settlement, and settlements are bigger, relative to stand-alone SEC investigations. The dynamics of settlement in class actions make it unlikely that individual officers will contribute to the settlement of class actions, so settlements may be only weakly tied to individual deterrence. We therefore look to an alternative measure of consequences for corporate officers: executive turnover. We find that CEOs and CFOs are more likely to resign under circumstances related to a stand-alone class action filing as opposed to a stand-alone SEC investigation.

Overall, the evidence we present here undercuts the conventional wisdom with regard to the relative merits of SEC enforcement and securities fraud class actions. Clearly, the strongest cases are those in which the SEC and the class action bar are both proceeding against a company. The more surprising result of our study, however, is that when the SEC or the class action bar go it alone, class actions are more closely associated with unreliable disclosures than are SEC investigations. Moreover, stand-alone class actions appear more likely to result in settlements, and those settlements are of greater magnitude, than standalone SEC investigations, and officers are more likely to be terminated. Our findings cast 


\section{SEC v. Class Actions}

doubt on the claim that SEC investigations are superior to class actions in targeting fraud and imposing sanctions on companies.

We proceed as follows. We review prior literature relating to SEC enforcement actions and securities class actions in Part 2 and develop our hypotheses. Part 3 describes our sample and variables, and reports the results of our empirical tests. Part 4 concludes.

\section{Prior literature and hypotheses}

\subsection{Market measures of fraud}

Numerous studies have shown significant stock price reactions to the announcement of potential fraud. (Kinney \& McDaniel, 1989; Karpoff \& Lott, 1993; Palmrose et al., 2001). Similar results are found for studies focusing specifically on SEC enforcement actions (Feroz et al., 1991; Karpoff et al., 2008a; Nelson et al. 2009; Griffin and Sun, 2011) and for securities fraud class actions (Griffin et al., 2004). The long run stock price performance of firms accused of fraud does not differ, however, from that of similar firms (Marciukaityte et al. 2006; Bai et al. 2010). These findings confirm the common sense intuition that the discovery of potential fraud is bad for companies, at least in the short run, but they offer little basis to distinguish between different types of enforcement mechanisms to combat fraud.

A number of studies have looked at the effects of potential fraud on the information environment for the company's common stock. The study most closely linked to this one is Dechow et al. (1996). Studying a sample of companies charged by the SEC in accounting enforcement actions, they find an increase in the bid-ask spread, a drop in analyst following, an increase in short interest, and an increase in the dispersion of analysts' 


\section{SEC v. Class Actions}

earnings forecasts. They do not include securities class actions, however, in their sample. These findings are confirmed by later work. Murphy, Shrieves and Tibbs (2009) show that share price responses for firms accused with misconduct correlate with subsequent changes in the level of certainty about earnings. The number of analysts declines significantly after a restatement (Griffin, 2003), as does institutional ownership (Burns et al., 2010). On a similar note, Hegde et al. (2010) find that trading volume drops significantly in the long term after a fraud disclosure leading to a securities fraud class action.

\subsection{Consequences}

Cox et al. (2004) find that securities class actions lead to larger settlements when there is also a parallel SEC enforcement proceeding. They do not, however, examine SEC enforcement proceedings in which no class action is filed. Karpoff et al. (2007) find that both government penalties and class action settlements are related to the magnitude of the harm. In related work, Karpoff et al. (2008b) find that over 90 percent of the individuals identified as responsible for fraud lose their jobs by the end of the enforcement proceedings. Niehaus \& Roth (1999) find that turnover of CEOs is higher for companies named in securities class actions. This result is confirmed by Humphrey-Jenner (2012), who also finds that CFOs are more likely to be terminated after the filing of a securities class action.

\subsection{Hypotheses}




\section{SEC v. Class Actions}

Our goal is to compare the relative importance of SEC investigations and securities class actions in targeting and deterring securities law violations. To do so, we split our cases into three categories: SEC, Both, and Class Action. The SEC category involves investigations of public companies where only the SEC is involved in the investigation and eventual litigation if any. The Class Action category involves filings against public companies with only private plaintiffs' attorneys filing suit. The Both category involves both the SEC and private plaintiffs' attorneys.

For our comparison of SEC investigations and securities class actions we use the Both category as the baseline of our comparison. We compare the relative merits of SEC and Class Action categories against the Both category to assess the separate deterrence value of SEC investigations compared with class action filings.

We use the Both category as the baseline for three reasons. First, by definition the Both category encompasses situations where both the SEC and private plaintiffs' attorneys separately decided to initiate an action (an investigation in the case of the SEC and a class action filing in the case of private plaintiffs' attorneys). In such cases, there is no a priori basis for assuming that the SEC or a class action would provide better deterrence and thus no reason to favor either SEC or class action enforcement. Either the SEC or the class action may go first, and in many cases it will be impossible to say that the earlier of the two is the "cause" of the latter-investigation may have been ongoing at the time the earlier action is revealed. In fact, for our Both sample, the SEC initiated investigation first in 116 of the cases, the class action was filed first in 117, and 2 cases were commenced the same day. Second, prior work (Dyck et al. 2010) finds that only a small percentage of fraud is uncovered by either the SEC or the class action bar. In many cases, the Both category 


\section{SEC v. Class Actions}

involves cases with public indicia of fraud. For example, companies that restate prior earnings are likely to attract the attention of both the SEC's Enforcement Division and the plaintiffs' bar. The trigger for both the SEC and private action is not investigation on the part of the SEC or a plaintiffs' attorney, but instead the company's own disclosure of the restatement. Moreover, because of the public indicia of fraud, it is likely that the SEC and a private class action suit will have a similar probability of success. The high likelihood of obtaining a settlement of judgment in such cases, in other words, will be driven by the public indicia of fraud and not by any investigative work on the part of the SEC or plaintiffs' attorneys. Eliminating either the SEC or the Class Action, while leaving the other type of enforcement in place, is unlikely to diminish deterrence in such a case.

Third, the Both category provides a benchmark for meritorious actions with which we can assess the merits of the SEC and Class Action categories. The fact that both the SEC and private plaintiffs' attorneys separately decided to bring an action is likely due to the more egregious nature of the underlying securities law violation. If the SEC or Class Action categories pursue underlying securities law violations involving public companies that do not harm investors as much, we expect that these categories will compare unfavorably relative to the Both category.

Our tripartite division allows us to construct a number of testable hypotheses. In particular, we are interested in testing the proposition that private securities class actions add little deterrence beyond that provided by SEC investigations. Comparing the SEC and Class Action categories against the Both category allows us to assess how the SEC and private plaintiffs' attorneys target actions when no obvious indicia exists indicating a securities law violations, as is often the case for Both actions, and thus where SEC and 


\section{SEC v. Class Actions}

private plaintiffs' investigation efforts and targeting decisions are more important. The comparison also allows us to assess the impact of eliminating either SEC or private plaintiffs' attorney actions on marginal deterrence, as this will eliminate either the SEC or Class Action category completely. Eliminating the SEC or plaintiffs' attorneys from the Both category will still leave the other to enforce in such cases, so for purposes of marginal impact on deterrence we are interested in the comparison between the SEC and Class Action categories. If actions in the Class Action category compare unfavorably to our SEC category, this finding would support the argument that private enforcement provide less in the way of marginal deterrence than does SEC enforcement.

For our comparison we rely upon several different metrics used in prior literature to distinguish the magnitude of the underlying securities law violation. The first metric, abnormal stock returns, is somewhat ambiguous, as it may reflect disclosure of problems with the firm's underlying business as much as the market's response to the revelation of fraud. Moreover, class action plaintiffs need to demonstrate loss causation, while the SEC does not, so this is likely to influence the selection of targets. Our other market metrics, however, have been accepted in the literature discussed above as proxies for the reliability of disclosure. Finally, we also look at two measures of deterrent sanctions: settlements and officer resignations.

These metrics give us the following hypotheses:

H1: Companies targeted by Class Actions will have a more negative cumulative abnormal stock market return relative to SEC companies.

H2: $\quad$ Companies targeted by Class Actions will have a smaller drop in institutional ownership relative to SEC companies.

H3: $\quad$ Companies targeted by Class Actions will have smaller increase in analyst earnings per share forecast dispersion relative to SEC companies. 


\section{SEC v. Class Actions}

H4: Companies targeted by Class Actions will have a smaller reduction in share turnover relative to SEC companies.

H5: Companies targeted by Class Actions will have a smaller increase in bidask spread relative to the SEC companies.

H6: $\quad$ Companies targeted by Class Actions will be less likely to pay settlements, and those settlements will be smaller relative to SEC companies.

H7: Officers of companies targeted by Class Actions will be less likely to be terminated relative to SEC companies.

\section{Data and empirical results}

\subsection{Sample}

Our sample consists of securities class actions filed against, and SEC investigations disclosed by, public companies from 2004 through 2007. We obtained the securities class actions from the Stanford Securities Class Action Clearinghouse. We identified the SEC investigations through NEXIS searches as well as searches of SEC filings by public companies. As the SEC typically does not disclose its investigations unless and until it files an enforcement action, our search relies on disclosures by companies that they are under investigation. Disclosure of an SEC investigation is not mandated by the SEC; consequently, we may miss SEC investigations that the company deems immaterial. We conjecture, however, that these undiscovered SEC investigations likely involved few SEC resources and are of only small economic importance. We use securities price data available on the Center for Research on Security Prices (CRSP). CRSP data was available for all firms in the SEC category, all but 2 firms from the Both category, and 12 firms from the Class Action category.

\section{[Insert Table 1 here.]}




\section{SEC v. Class Actions}

Table 1 reports descriptive statistics for the sample. We see that the SEC and Class Actions categories are roughly similar in number, with substantially fewer companies in the Both category. The Both category stands out for having a substantially higher percentage of firms reporting restatements, generally regarded as a proxy for case strength in the literature on class actions. For firm size, the mean size of Class Action targeted firms is somewhat lower than firms in the SEC and Both categories, but the Class Action firms still average over $\$ 9$ billion in market capitalization. The median for the Class Actions firms is substantially smaller than the other two categories, however, at only $\$ 764$ million. This suggests that the SEC is not targeting smaller firms. When we look at mean adjusted returns in the year prior to the negative disclosure of the underlying securities law violation, the Class Action companies have a negative return, on average, while the SEC and Both categories are each positive.

\subsection{Event study}

We begin by examining the abnormal stock price reaction in response to the disclosure of the bad news for the firms relating to the underlying securities law violation in each of our categories. We start with event windows for our studies focusing on the date of the first public disclosure of the securities law problem leading to the investigation or the class action, which we label the Violation Date. For example, a company may announce an internal investigation into accounting issues. That announcement may lead the market to expect an SEC investigation prior to the first public announcement of that SEC investigation. For comparison purposes, we also use a window centered on the first public disclosure of the SEC investigation, for the SEC and Both categories, or the class action, for 


\section{SEC v. Class Actions}

the Class Action category, which we label the Action Date. For our sample, the mean number of days between the Violation Date and the Action Date was as follows: 73 days for the SEC category, 133 days for the Both category, and 112 days for the Class Action category. As theory suggests that the stock market reaction will be negative, we use onesided tests of significance. We present the results in Table 2.

\section{[Insert Table 2 here.]}

The first set of event studies measures the stock market's response to the underlying problem. The clear message from this table is that large stock price drops put firms on the radar screen of the plaintiffs' bar. This finding is not surprising given the role that such declines play in establishing loss causation and damages. The Class Action category has by far the strongest negative reaction, an average drop of $-21.90 \%$. The Both category is a still substantial $-12.73 \%$, but the SEC category is a mere $-2.09 \%$. The greater magnitude of the stock market reaction to the first public announcement of the underlying problem for the Class Action category is consistent with private plaintiffs' attorneys targeting actions with a greater impact on investors compared with the SEC category. This evidence would suggest that the SEC, when it goes it alone, is not targeting firms for investigation on the basis of a negative stock market reaction. If the stock market is used as a metric of the egregiousness of the harm to investors, private plaintiffs' attorneys target more egregious harms than the SEC, which is consistent with Hypothesis 1.

It is possible that the market may not fully respond to the first public disclosure of the underlying securities law violation. Instead, the market may react upon the later announcement of the start of an SEC investigation or initiation of a class action suit. To test this possibility, we conduct an event study centered on the first public disclosure date 


\section{SEC v. Class Actions}

of the SEC investigation or Class Action filing date (and in the case of the Both category, the date of the SEC investigation).

Table 2 presents the results for the first disclosure of an SEC investigation or the filing of a class action. Here the range is much narrower. The disclosure of an SEC investigation generates only a $-1.80 \%$ abnormal response from the market, which is similar in magnitude for the response to the initial disclosure of the bad news that leads to an SEC investigation. The Both category, however, provokes a considerably larger $-4.83 \%$ response to the disclosure of the SEC investigation. In contrast, the market response to the disclosure of the Class Action filing is only $-2.23 \%$. The market reaction to the initial disclosure of filing of a class action is greater than for the disclosure of an SEC investigation when the two do not accompany each other, but the difference is not substantial. ${ }^{1}$

It is also possible that the stock market reaction may encompass other negative effects on the firm, including the expected distraction cost and direct litigation cost the company is likely to incur in defending an action, whether or not it is meritorious. This is a largely fixed cost, not closely tied to the likelihood of fraud. Importantly, the cost of defending against the SEC may be higher than the cost of defending against a private action. As noted above, defense costs for defending a company involved in an SEC investigation are substantial. Based on defense costs, the stock market reaction to an SEC investigation should be more negative than the reaction to a Class Action filing. We find the opposite, however.

\footnotetext{
${ }^{1}$ As a robustness test, we performed the event study for the Both category using the earlier of the SEC investigation or the Class Action filing. The results are qualitatively similar.
} 


\section{SEC v. Class Actions}

\subsection{Market tests of information asymmetry}

We present a series of tests that provide another means of assessing the magnitude of a securities law violation. These tests measure the impact of the violation on the amount of information asymmetry in the market and the market's assessment of the reliability of the company's management and disclosures. We conjecture that more serious securities law violations will cause investors in the marketplace to lose trust in a company's management and its ability to provide accurate disclosures, thus increasing the amount of perceived information asymmetry in the marketplace.

\subsubsection{Changes in Institutional Ownership}

For our first set of tests of the market's assessment of the reliability of management and a company's disclosures, we examine changes in institutional ownership. Our measure of institutional ownership is the sum of $13 \mathrm{~F}$ ownership for a particular quarter divided by the shares outstanding. We obtain the data on 13F filings from Thomson Reuters. As with our event studies, we focus on two dates: (1) Violation Date, the date the underlying securities law problem is first disclosed; and (2) Action Date, the date the SEC investigation is disclosed (for the SEC and Both categories) or the class action is filed (for Class Action). Institutions are required to file $13 \mathrm{~F}$ forms quarterly, so our measures rely on those reporting dates. We calculate the difference between: (1) the level of institutional holdings for the quarter four quarters prior to the quarter that includes the relevant date; and (2) the level of institutional holdings for the quarter four quarters after the quarter that includes that date. Our hypothesis is that institutional investors, who tend to be relatively active investors, will reduce their holdings in companies accused of violating the securities 


\section{SEC v. Class Actions}

laws due to a loss of trust in management and a fear of inaccurate disclosures. Table 3, Panel A presents the means of these changes for our three categories around the Violation date and the Action date. We also present t-tests comparing the means for Both and Class Action with the mean for SEC.

\section{[Insert Table 3 here.]}

Overall, we observe significant difference in the reaction of institutional investors. For the Both category, mean institutional ownership declines around both the Violation Date and the Action Date. In contrast, institutional investor ownership increases for the SEC category for the Violation and Action dates and the difference with the Both category is significant for both of the dates. Similarly, institutional investor ownership increases for the Class Action category for the Violation and Action dates, although the difference with the Both category is not significant. These descriptive statistics offer support to the hypothesis that institutional investors perceive differences among our three categories and that they reduce ownership for the Both category, particularly relative to the SEC category.

Of course, a variety of factors can affect levels of institutional ownership. To control for these factors, we use the change in means of institutional ownership as a dependent variable in an ordinary least squares regression with robust standard errors. The base category for these regressions is Both; we include indicator variables for SEC and Class Action. We also include indicator variables if the investigation or action involved an accounting problem or a restatement. We use two linear variables, the log of Market Capitalization and Adj. Ret., which we define as the one-year return up to 1 week prior to first public disclosure date, adjusted by the value weighted CRSP index return for the same period. Finally, we include industry indicator variables based on two-digit SIC codes for 


\section{SEC v. Class Actions}

these regressions, as well as those that follow. For ease of presentation we do not tabulate the coefficients for the industry variables. The results of these estimations are presented in Table 3, Panel B.

The coefficients for SEC are positive in both institutional change models (significant at the $1 \%$ and $5 \%$ level respectively). Compared with the Both category, the SEC category correlates with an increase in the amount of institutional investor ownership. For our sample, institutional investors are more willing to hold the shares of a company that faces an SEC investigation compared with firms that face both the SEC and private plaintiffs' attorneys. In contrast, the coefficients for Class Action are not significantly different from zero in both institutional change models. Although the Class Action category is similar to the Both category in terms of change in institutional investor ownership, the SEC category correlates with greater institutional investor ownership—consistent with investors not shunning firms in the SEC category. The differences between the SEC and Class Action coefficients are significant at the $5 \%$ levels in the two models, which is inconsistent with Hypothesis 2.

\subsubsection{Changes in Analyst Forecast Dispersion}

For our next set of tests of the market's assessment of the reliability of management and a company's disclosures, we examine dispersion in analysts' forecasts of earnings per share. A securities law violation is likely to reduce analysts' confidence in company disclosures, thereby increasing uncertainty over future earnings. We follow Dechow et al. (1996) in measuring dispersion as standard deviation of all analyst forecasts made in the last month before the end of the fiscal year in question. We exclude observations for which 


\section{SEC v. Class Actions}

there are less than two forecasts. We use forecast dispersion for one year prior to the year of the disclosure date and one year subsequent. We present the descriptive statistics in Panel A of Table 4.

\section{[Insert Table 4 here.]}

Here we see a consistent story of increased dispersion in earnings per share forecasts; the means are positive for all the categories for both the Violation Date and Action Date. We use t-tests to compare the means for our three categories. The Both category has a greater increase in forecast dispersion than the SEC and Class Action categories, although the difference is only significant (at the $10 \%$ level) between the SEC and Both categories. These differences suggest that analysts have the greatest increase in uncertainty with regard to disclosures made by firms in the Both category.

We next use the change in analyst forecast dispersion as our dependent variable in an ordinary least squares regression. SEC and Class Action are again independent variables in these models, with Both as the base category. We use the same control variables as our regressions for institutional ownership, with the exception that we substitute the number of analysts one year after the year of disclosure for the log of Market Capitalization and Adjusted Return. We present the results of these estimations in Panel B of Table 4.

Here the coefficients for SEC and Class Action are negative, but significant only at the ten percent level. This provides some support for the proposition that analysts view the disclosures of firms in the Both category as being less reliable. The F-tests comparing the SEC and Class Action coefficients are insignificant for both models. Overall, we conclude that earnings per share forecast dispersion increases for firms suspected of a securities law violation, but we cannot distinguish between the SEC and Class Action 


\section{SEC v. Class Actions}

categories with respect to this measure of the credibility of firm disclosures. Thus, we find no support for Hypothesis 3.

\subsubsection{Changes in Share Turnover}

We next test for changes in stock turnover. Daily turnover is the number of shares traded daily divided by the number outstanding. We compute turnover for two periods ranging from -130 to -40 calendar days and +40 to +130 calendar days centered on the Action and Violation dates respectively. Turnover for each period is defined as $1-(1-\text { Average Daily Turnover })^{\wedge}$ Number of Trading Days. The change in turnover is then calculated as the difference between the two periods. The prediction is that trading volume will decline because investors will perceive a greater likelihood of information asymmetry. We present descriptive statistics on trading volume in Panel A of Table 5.

\section{[Insert Table 5 here.]}

With respect to the Violation date, the Both category induces a significantly greater change in the volume of trading than the other two categories. Notably, the Class Action category has a mean decline in trading volume of 3.2\%, while the Both category has a mean increase of 3.4\%; this difference is significant at the $1 \%$ level. In contrast, the SEC category does not experience a large change in turnover (with a mean increase of $0.6 \%$ ); the difference between SEC and Both is significant at the 5\% level. The means for the Action date display a similar pattern. The Class Action category has a mean decline in trading volume of $3.1 \%$, while the Both category has a mean decline of only $1.5 \%$; the difference however is not significant. The SEC category does not experience a large change in 


\section{SEC v. Class Actions}

turnover (with a mean increase of $0.6 \%$ ); the difference with the Both category is significant at the $10 \%$ level.

We use the change in turnover as our dependent variable in ordinary least squares regressions. SEC and Class Action are independent variables in these regressions, along with Accounting, Restatement, Market Capitalization, and Inst. Ownership (Post), measured as the level of institutional holdings for the quarter four quarters after the quarter that includes the Violation Date or Action Date. Model 1 uses the change in turnover around the Violation Date as the dependent variable. Model 2 uses the change in turnover around the Action Date as the dependent variable.

In Model 1, the coefficient on SEC is negative, but insignificant, while the coefficient for Class Action is negative and significant at the $1 \%$ level. The coefficient on Class Action is more negative than the coefficient on SEC (difference significant at the $1 \%$ level). The market reacts with a relatively greater decline in turnover for Class Action compared with the SEC category. This finding is inconsistent with Hypothesis 4. In Model 2, we report that the coefficient on SEC is now positive and significant at the $10 \%$ level, while the Class Indication variable is negative but insignificant. The difference between these two coefficients is significant at the $1 \%$ level, indicating that turnover declines for the Class Action category relative to the SEC category. This result is inconsistent with Hypothesis 4.

\subsubsection{Changes in Bid-Ask Spread}

Our final set of market tests looks at a measure of information asymmetry, bid-ask spread. If market participants believe that there is information asymmetry among the traders for a company's shares, they will incorporate that possibility into the trading cost. 


\section{SEC v. Class Actions}

We first estimate a model for the predicted bid-ask spread using all Nasdaq companies for 2004 to 2007 . We then compute the residual bid-ask spread for the days -130 to -40 and +40 to +130 around the Violation Date and the Action Date. The residual spread for each firm is its actual bid-ask spread minus the predicted bid-ask spread. We then compare the difference between the residual spread for the two periods. We present the mean change in residual bid-ask spread in Panel A of Table 6.

\section{[Insert Table 6 here.]}

Overall, we see a decrease in the residual bid-ask spread for each of our categories, which is inconsistent with market makers expecting an increased risk of informed trading. Notably, the Both category has the largest decrease in the residual bid-ask spread for both dates. There are no significant differences for the means.

To test further the relation between the bid-ask spread for the Class Action and SEC categories, we estimate an ordinary least squares model with the mean difference in the residual daily bid-ask spread as the dependent variable and SEC, Class Action, and PostViolation as independent variables. We also include Accounting, Restatement and the log of market capitalization as independent variables, with robust standard errors. The results of the estimation are presented in Panel B of Table 6.

The coefficients for both SEC and Class Action are not significantly different from zero. Relative to the Both category, the residual bid-ask spread for these categories did not change significantly. We also find no significant difference in the change between the bidask spread for the SEC category relative to the Class Action category. This result offers no support to Hypothesis 5. 


\section{SEC v. Class Actions}

\subsection{Sanctions and consequences}

In the prior section, we presented a series of tests that attempted to capture the market's assessment of the potential for information asymmetry and the reliability of the company's management and disclosures. Those measures were intended to evaluate the targeting of the action in each of our categories. In this section, we turn to the deterrent impact of the actions in our sample. Do SEC investigations lead to more serious consequences than class actions? We evaluate this question from the perspective of both the firm and the individual. For the firm, we examine both the likelihood of settlement and its amount. For the individual, we look at the likelihood that the CEO or CFO will be terminated in the wake of an allegation of fraud at the company.

\subsubsection{Settlements}

We obtained the settlement outcomes for the SEC investigations from the SEC's enforcement releases. For the class action settlements, we obtain the settlement amount from the settlement notice provided to the shareholder class members. The incidence and amounts of settlements are compared for our three categories in Table 7, Panel A. For the Both category, we report separately the incidence of either an SEC or Class Action settlement.

\section{[Insert Table 7 here.]}

Consistent with our market tests, we find that the Both category is considerably more likely to result in a SEC settlement than an SEC investigation that is not accompanied by a class action. Over $40 \%$ of the SEC investigations resulted in a settlement for the Both category, compared to 21\% when only the SEC investigated. The difference between these 


\section{SEC v. Class Actions}

two means is significant at the $1 \%$ level. For those investigations that lead to a settlement, however, there is no significant difference in the amount of monetary penalty extracted by the SEC, with both categories hovering around \$13 million. It appears that the SEC investigation in the Both category lead to fewer dry holes for the agency, but when the SEC decides to proceed with an enforcement action when it is going it alone the consequences are similar for the company involved.

Turning to the differences between Both and Class Action, the Both category is significantly more likely to lead to a settlement in the class action, with $58 \%$ of those suits producing a settlement compared with $43 \%$ in the Class Action category. This difference is significant at the $1 \%$ level. Moreover, the size of the Both settlements is much greater, with a mean of $\$ 52$ million, compared to only $\$ 15$ million for the Class Action category. This difference in class action settlements suggests that the violations in the Both category are considerably more serious.

In order to explore these differences in greater depth, we use the incidence of a settlement as the dependent variable in a series of logit models. For our control variables, we use indicator variables for an accounting problem or a restatement. We also include the log of market capitalization. We present the results of these estimations in Table 7, Panel B.

The first model uses only the SEC indicator variable, with Both as the baseline category. The coefficient for SEC is negative and significant at the $1 \%$ level. This result confirms that the SEC category is significantly less likely to lead to a settlement than the Both category. For the control variables in this model, it is worth noting that the coefficient for Accounting is negative and significant at the 1\% level. Apparently, the SEC is less inclined to insist upon a settlement if the accounting problem does not warrant a formal 


\section{SEC v. Class Actions}

restatement. The Market Cap. control variable is also positive and significant at the $5 \%$ level, suggesting that the SEC is more likely to insist on a settlement from larger companies, perhaps because of ability to pay.

In Model 2, we limit the sample to the Both and Class Action categories and use as our dependent variable the incidence of a settlement in the class action. In this model, Both is the base category and we include an indicator variable for the Class Action category. The coefficient for Class Action is negative and significant at the $5 \%$ level, suggesting that settlement is more likely for the Both category than for the Class Action category. Our control variables that may proxy for strength of case are consistent with this finding: Restatement is positive and significant at the $1 \%$ level, while Market Cap. is negative and significant at the $1 \%$ level. The latter finding is consistent with a decision model in which plaintiffs' are willing to bring somewhat weaker cases on the merits if the potential damages are greater.

In Model 3, we use as our dependent variable the incidence of a settlement in either the SEC investigation or the class action. We also include the other independent variables as in Models 1 and 2. The coefficients for both SEC and Class Action are negative and significant at the $1 \%$ level. Both the SEC and Class Action categories are less likely to settle compared with the Both category. The coefficient on SEC is more negative than the Class Action coefficient. (An F-test confirms that the difference is significant at the $1 \%$ level.) This finding is consistent with the SEC category being less likely to produce a settlement than the Class Action category. This suggests that when either the SEC or the class action bar go it alone, the SEC's investigations may be less likely to produce deterrent impact than class action filings. This evidence contradicts Hypothesis 6. 


\section{SEC v. Class Actions}

We next look at the magnitude of the settlements. For this set of regressions, we limit the sample to cases in which there was a settlement with either the SEC or in the class action. We use the amount of those settlements as our dependent variable in a series of ordinary least squares regressions. We present the results in Panel C of Table 7.

In Model 1, we limit the sample to the Both and SEC categories, with the former as the baseline and an indicator variable for the latter category. We use as our dependent variable the log of the total monetary settlement won by the SEC against both the company and individuals. We find that the SEC category has a positive coefficient, but it is not significant. This finding suggests that although the Both category is more likely to produce a settlement, those settlements are similar in amount to the SEC category.

In Model 2, we look at class action settlements, restricting the sample to the Both and Class Action categories with Both as the base category. In this estimation, the coefficient for Class Action is negative and significant at the $1 \%$ level. The Both category is not only more likely to produce a settlement compared with the Class Action category, the settlements in the Both category are also larger.

In Model 3, we aggregate the settlements from the SEC investigations and class actions for our dependent variable and include all three categories in our sample. We use Both again as the base category, with indicator variables for SEC and Class Action. The Class Action coefficient is negative, but insignificant, which suggests that the aggregate sanction is no greater for the Both category than for the Class Action category. The SEC coefficient, however, is negative and significant at the $1 \%$ level. This suggests that SEC investigations produce smaller aggregate sanctions than the Both category. Moreover, an F-test confirms that the SEC coefficient is significantly smaller than the Class Action 


\section{SEC v. Class Actions}

coefficient (significant at the 1\% level), so the aggregate sanction is also smaller for the SEC category relative to the Class Action category, again contradicting Hypothesis 6.

\subsubsection{Officer terminations}

For our last set of tests, we examine whether the CEO or CFO resigned or was terminated due to the subject matter of the underlying securities violation (Officer Resign). Panel A reports that the SEC investigations had the lowest incidence of Officer Resign at just under a third. Both actions involved the highest incidence of Officer Resign at slightly over half; the difference with SEC is significant at the one percent level. Class Action resignations were marginally higher than SEC Actions; the difference, however, is not significant.

As a multivariate test, we estimate a logistic regression model with Officer Resign as the binary dependent variable; resignation is coded as 1 . For our control variables, we use indicator variables for an accounting problem, or a restatement. We also include the log of market capitalization and adjusted return (defined as the one-year return up to 1 week prior to first public disclosure date, adjusted by the value weighted CRSP index return for the same period). We present the results of these estimations in Model 1 of Panel B of Table 8.

Note that the coefficient on SEC is negative and significant at the $1 \%$ level, indicating that the incidence of CEO or CFO resignation is smaller for SEC actions compared with the base Both category. The coefficient on Class Action is negative, but significant at only the $10 \%$ level. The coefficient on SEC has a greater negative magnitude compared with Class Action (an F-test of the difference is significant at the 1\% level), contradicting Hypothesis 7. The incidence of CEO or CFO resignation is lower for SEC investigations - suggesting that in 


\section{SEC v. Class Actions}

stand-alone investigations, the SEC tends to pursue more cases involving less egregious securities law violations than private plaintiffs' attorneys.

\subsection{Robustness tests}

To assess the robustness of our conclusions we repeated our statistical analyses described above using a range of subsamples. First, we used subsample of investigations and class actions that survived an initial screening process, and then those that resulted in settlements. The rationale for choosing these subsamples was that they provided a window on the relative strength of the screening processes used in the SEC and Class Action categories, while continuing to provide an apples-to-apples comparison. Second, we included control variables to distinguish among the types of SEC investigations, in an effort to understand the lack of support for the hypothesis of SEC superiority.

\subsubsection{Screened Subsamples}

We wanted to see if there were differences among our categories for investigations/cases that had survived an initial screening process. For the SEC investigations, we use formal orders of investigation (SEC (Formal)). For the Class Action category, we identify cases that have survived a motion to dismiss by the defendants (Class Action (Survive MTD)). For the Both category, we identify situations in which both the SEC has made a formal order of investigation and the class action has survived a motion to dismiss (Both (Formal + Survive MTD)). For the SEC investigations, the staff has determined that there is enough evidence of a securities law violation to warrant the request of a formal order of investigation. For the class actions, a court has determined that the plaintiff's complaint alleges sufficient indicia of fraud to meet the heightened 


\section{SEC v. Class Actions}

standards imposed by the Private Securities Litigation Reform Act. Our hypothesis is that each of these subsamples would reflect greater indicia of information asymmetry and greater likelihood/magnitude of sanctions. But would our metrics for these characteristics be stronger for any of our three categories? If so, that would suggest that the screening process(es) for that category was more rigorous in identifying cases of likely fraud.

We provide descriptive statistics for this sub-sample in Table 9. We see that same percentage-35.3\% - of SEC and Both are likely to survive the initial screening process. Class actions are substantially less likely to be terminated at an early stage, with $51.1 \%$ surviving a motion to dismiss. Turning to the characteristics of the actions, Restatements are a prominent feature of the cases in the Both category that survive, with $70.7 \%$ of those firms restating their financial statements. The other notable characteristic from the descriptive statistics is the Market Cap. of firms in the SEC (Formal) category, which has a mean of over $\$ 20$ billion, while the means for the firms in the Both (Formal + Survive MTD) and Class Action (Survive MTD) are both under $\$ 9$ billion.

We summarize the (untabulated) results from our statistical analysis using this subsample here. Both (Formal + Survive MTD) now provides the base category, and we include indicator variables for SEC (Formal) and Class Action (Survive MTD). Generally speaking the results were qualitatively similar. For the event study, the stock price reactions were similar in magnitude to those found for the larger sample, although the returns for the Class Action (Survive MTD) are slightly more negative $(-23.18 \%$ for the Violation Date and $-3.67 \%$ for the Action Date) than those presented in Table 2. These similar reactions do not suggest that the market has anticipated the relative strength of these cases. 


\section{SEC v. Class Actions}

The results were also similar for the tests of information asymmetry. For the regressions examining changes in institutional holdings, the SEC (Formal) coefficients are positive and significant for both dates, but they are not significantly different from the coefficients for Class Action (Survive MTD) for either date. For the changes in turnover, the results are qualitatively similar, the Class Action (Survive MTD) coefficient showing a significantly greater decline in turnover relative to the SEC (Formal) coefficient in both models, at the $1 \%$ and $5 \%$ levels respectively. The regressions examining changes in earnings per share forecast dispersion and the bid-ask spread showed insignificant differences between the coefficients for SEC (Formal) and Class Action (Survive MTD). Overall, none of the tests using this screened subsample offers support to Hypotheses H2H5.

Turning to sanctions, when we examine the likelihood of settlement, the results are somewhat weaker than those presented in Table 7, Panel B, but the differences between SEC and Class Action are still significant. The SEC (Formal) coefficient for Model 1, while negative, is no longer significant; the coefficient on Class Action (Survive MTD) in Model 2 is negative but now significant at only the $10.7 \%$ level, just beyond conventional levels of significance. In Model 3, the coefficient on SEC (Formal) remains negative and significant at the $1 \%$ level while the coefficient on Class Action (Survive MTD) is negative but no longer significant. The difference between the two is significant at the $1 \%$ level. Looking at settlement magnitude, the results qualitatively similar as in Table 7, Panel C, with the exception that the coefficient for Class Action (Survive MTD) in Model 3 is negative and significant at the $1 \%$ level. An F-test confirms, however, that the SEC (Formal) coefficient is significantly more negative than the coefficient for Class Action (Survive MTD). These 


\section{SEC v. Class Actions}

results contradict Hypothesis 6. Looking at officer terminations, we get the same qualitative results as the estimation in Table 8, Panel B. The coefficient on SEC (Formal) has a greater negative magnitude compared with Class Action (Survive MTD) for this estimation. An F-test confirms that the difference is significant at the $5 \%$ level. This result again contradicts Hypothesis 7.

It is possible that our screened sub-samples do not accurately map the screening process because the process is not complete until the case is finally settled. To address this concern, we narrowed the screened categories to include only cases that led to a settlement: SEC (Settle) and Class Action (Settle). For the Both category, we limited this subsample to cases in which the SEC secured a settlement: Both (Settle).

The event studies show abnormal returns that are qualitatively similar to those presented above, with the returns for the Class Action (Settle) $(-23.75 \%$ for the Violation Date and $-3.63 \%$ for the Action Date) similar to those for Class Action (Survive MTD). The results for the tests of information asymmetry were also similar to those presented above. For the regressions examining changes in institutional holdings, the SEC (Settle) coefficients are positive but insignificant for both dates, and are not significantly different from the coefficients for Class Action (Settle) for either date. For the changes in turnover, the results are qualitatively similar, the Class Action (Settle) coefficient showing a significantly greater decline in turnover relative to the SEC (Settle) coefficient in both models, with the difference significant at the $10 \%$ and $5 \%$ levels, respectively, for the Violation Date and Action Date. The regressions examining changes in earnings per share forecast dispersion and the bid-ask spread showed insignificant differences between the 


\section{SEC v. Class Actions}

coefficients for SEC (Settle) and Class Action (Settle). Once again, none of the tests using this screened subsample offers support to Hypotheses H2-H5.

Given the construction of these subsamples, we do not compare the incidence and amount of settlement. With regard to officer resignations, the coefficients for SEC (Settle) and Class Action (Settle) are both negative and significant (at the 1\% and 5\% levels, respectively). This finding suggests that both categories are less likely to lead to officer resignations than Both (Settle). The coefficients are not significantly different from each other, however, so this test offers no support to Hypothesis H7.

\subsubsection{Type of SEC investigation}

To this point, our tests have found little support for the proposition that SEC investigations are superior to Class Actions in targeting companies with unreliable disclosures, or imposing more serious sanctions. For our second set of robustness tests we focus on potential explanations for this pattern.

One possibility is that stand-alone SEC investigations sometimes target behavior that violates the securities laws, but does not directly implicate questions of disclosure quality or reliability. Generally speaking, those violations do not give rise to a cause of action for private plaintiffs. If those investigations do not create concerns about information asymmetry or reliability, the market may discount the importance of those SEC investigations.

Another possibility is that the SEC may bring investigations that are politically popular, but which target behavior that is of secondary concern to market participants. In 


\section{SEC v. Class Actions}

particular, in prior work (Choi et al. 2012), we have shown that the SEC invested substantial resources into investigating option backdating during the period covered by this study. In that work, we found that the SEC may have pursued backdating investigations at the expense of investigating other types of securities law violations with potentially greater impact on investors.

To test these possibilities, we split our SEC category in two different sub-categories. The first set of subcategories: 1) SEC Disclosure, which was coded to equal 1 if the SEC's stand-alone investigation involved an company's disclosures; and 2) SEC Non-Disclosure, which was coded to equal 1 if the SEC's stand-alone investigation involved other securities law issues. Included in the SEC Non-Disclosure category were investigations involving: 1) bribery under the Foreign Corrupt Practices Act (if the investigation did not also involve disclosure issues), 2) municipal securities, and 3) auction-rate securities. For the second set of subcategories, we replaced the SEC category with two alternatives: 1) SEC Option, which was coded to equal 1 if the SEC's stand-alone investigation involved option backdating; and 2) SEC Non-Option, which was coded to equal 1 if the SEC's stand-alone investigation involved other securities law issues.

For the event study, the stock price reactions for SEC Disclosure and SEC NonDisclosure were similar in magnitude to those found for the overall SEC category. This is was also true for the SEC Non-Option category. For the SEC Option category, however, the abnormal stock price reactions were considerably smaller: only $-1.07 \%$ for the Violation Date, and $-0.41 \%$ for the Action Date. This small reaction suggests that the market perceived the Option investigations as less important. 


\section{SEC v. Class Actions}

We then reestimated the regressions presented in Tables 3-8. For first set of these regressions, we replaced the SEC indicator variable with SEC Disclosure and SEC NonDisclosure. For the second set of regressions, we replaced the SEC indicator variable with SEC Option and SEC Non-Option.

The results (untabulated) were somewhat surprising. Relative to SEC NonDisclosure and Class Action, SEC Disclosure had a greater increase in institutional ownership and a smaller decline in share turnover. With minor exceptions, these differences were significant for both the Violation Date and the Action Date. ${ }^{2}$ There were no significant differences among the three coefficients for in dispersion of earnings per share forecasts and changes in the bid ask-spread. ${ }^{3}$ Overall these results suggest that SEC investigations involving disclosure issues - if not accompanied by a class action - give less concern to the market than investigations of issues not related to disclosure. Perhaps the fact that the class action bar could have pursued those disclosure issues, but chose not to, suggests they are of less importance to investors.

For the regressions using the SEC Option indicator variable, the results tell a less consistent story. For the regressions using changes in institutional ownership as the dependent variable, the SEC Option coefficient was positive and significantly greater than the coefficients for SEC Non-Option and Class Action. This finding suggests that institutional owners did not shy away from firms caught up in the backdating investigations. There were no significant differences among these coefficients for the regressions using increase in earnings per shares forecast dispersion. In the regressions

\footnotetext{
${ }^{2}$ For the institutional ownership regression, the difference between the SEC Disclosure and the SEC NonDisclosure coefficients was significant only in the regression for the Action Date (at the $10 \%$ level).

3 The only exception being that the SEC Disclosure coefficient was smaller than the Class Action coefficient for increase in bid-ask spread around the Action Date. The difference was significant at the $10 \%$ level.
} 


\section{SEC v. Class Actions}

examining changes in share turnover, the coefficient for SEC Option showed a significant decline relative to SEC Non-Option for the Violation Date, suggesting that investors were less willing to trade the shares of those firms. For the bid-ask spread regression, however, the SEC Option coefficient was not significantly different for the Violation Date, but for the Action Date there was a significant narrowing of the bid-ask spread for the SEC Option category relative to the SEC Non-Option category. Overall, these results do not support any firm conclusions.

We also examined the relation between these factors and the outcomes of investigations. These regressions are quite consistent. SEC Disclosure correlates with both a significantly lower likelihood and smaller magnitude of settlement relative to both SEC Non-Disclosure and Class Action. With regard to Officer Terminations, SEC Disclosure correlates with a significantly lower likelihood of resignation relative to Class Action. Overall, we conclude that the sanctions resulting from SEC Disclosure investigations are less severe.

We see a similar pattern with respect to SEC Option. SEC Option correlates with both a significantly lower likelihood and smaller magnitude of settlement relative to both SEC Non-Option and Class Action. With regard to Officer Terminations, SEC Non-Option correlates with a significantly lower likelihood of resignation relative to Class Action, but the difference between SEC Option and Class Action is not significant. As with SEC Disclosure investigations, the consequences flowing from SEC Option investigations are less severe for the company, but we do not find a difference for top level officers. 


\section{SEC v. Class Actions}

\section{Conclusion}

Critics of securities fraud class actions have traditionally pointed to SEC enforcement as a better alternative. The empirical evidence supporting that argument, however, largely comes from studies examining SEC enforcement actions, not SEC investigations. Enforcement actions, however, have been carefully screened by the SEC before filing, with the benefit of substantial pre-filing investigation. That sort of investigation is simply not available to the class action bar, which lacks subpoena authority and cannot gain access to discovery until after their complaints have survived a motion to dismiss. To put the two types of enforcement on a level playing field, we compare instead SEC investigations with class action filings.

Our first set of tests looked at the stock market reaction to the first public announcement of the underlying securities law violation and the first public announcement of the SEC investigation or Class Action filing. Compared to the Both category, we found that the Class Action category was based on significantly greater negative market reactions than the SEC category. Class action plaintiffs need to establish loss causation, so this result is not surprising, but it does not suggest that investors view SEC actions as responding to greater harm to investors than class actions.

Our next set of tests looked at market measures of the possibility of information asymmetry and responses of market participants to a loss of trust in the management of a company and the accuracy of the company's disclosures. Two of these tests (change in analyst earnings per share dispersion and bid-ask spread) failed to show any consistent differences between the Class Action and SEC categories. Our other two tests, however, involving the change in institutional investor ownership and share turnover, showed 


\section{SEC v. Class Actions}

evidence that the market viewed the Class Action category as correlating with more serious disclosure problems relative to the SEC category.

We find evidence that the incidence of settlements as well as the magnitude of the settlements is smaller for the SEC category relative to the Class Action category. When the SEC pursues investigations alone, it is less likely to win a settlement and, conditional on settlement, for less money compared with when private plaintiffs' attorneys pursue class actions alone. Thus, we have reason to question that SEC investigations lead to greater deterrent impact than class actions, at least at the company level.

Finally, we find evidence that the SEC category has a significantly lower incidence of top officer resignations compared with the base Both category and Class Action category. Using officer resignations as a proxy for the egregiousness of underlying securities law violations, the SEC category correlates with a lower level of harm compared with the Class Action category.

One potential criticism of our study is that the SEC or plaintiffs' attorneys may use the presence of the other as a trigger for their own involvement. For example, if the Both category includes situations where the SEC first uncovers a securities law problem and then plaintiffs' attorneys piggy-back on the SEC's efforts, then eliminating the SEC from public enforcement of such claims may reduce the incidence of actions even within the Both category. As we note above, however, most cases in the Both category involve situations in which the company itself disclosed the underlying problem, and the SEC and the plaintiffs' bar appear equally likely to be the first to pursue the matter. Moreover, actions in the Both category often display public indicia of fraud, most notably 


\section{SEC v. Class Actions}

restatements, which appear in the lion's share of investigations/actions that survive for that category.

There is another potential criticism of our approach in using the Both category as a baseline and focusing on the comparison of the SEC versus Class Action categories relative to this baseline. Eliminating either the SEC or plaintiffs' attorneys may affect the amount of enforcement - and thus deterrence - for companies targeted even in the Both category. The SEC, for example, enjoys a broader array of penalties it can levy against a public company and its officers compared with plaintiffs' attorneys.

Overall, however, our findings offer little support to commentators who call for a shift from private actions to greater public enforcement. We found that class action only filings focus on securities law violations that are comparable to, and in some tests, greater than the violations on which the SEC alone focuses. Our results suggest that private plaintiffs' attorneys, if anything, provide greater deterrence against more serious securities law violations compared with the SEC.

Our paper does not look at all aspects of how SEC enforcement might differ from private class action enforcement. Our focus is on public company level enforcement. In contrast, class actions do not compare as favorably when it comes to individual deterrence; class actions settlements seldom include contributions from officers. Nonetheless, our paper provides evidence that at a company-level of deterrence, the case for SEC enforcement over class actions is far from clear. 


\section{References}

Agrawal, A.m J. Jaffe and J. Karpoff. Management Turnover and Corporate Governance Changes Following the Revelation of Criminal Fraud, Journal of Law and Economics, 62 (1999), 309-342.

Bai, L., J.D. Cox, and R.S. Thomas, Lying and Getting Caught: An Empirical Study of the Effect of Securities Class Action Settlements on Targeted Firms, University of Pennsylvania Law Review 158 (2010) 1877-1914.

Bratton, W.W., and M.L. Wachter. The Political Economy of Fraud on the Market, University of Pennsylvania Law Review 160 (2011) 69-168.

Burns, N., S. Kedia and M. Lipson, Institutional Ownership and Monitoring: Evidence from Financial Misreporting, Journal of Corporate Finance 16 (2010) 443-455.

Cheng, C.S. A., H.H. Huang, Y. Li, and G. Lobo. Institutional Monitoring Through Shareholder Litigation. Journal of Financial Economics 95 (2010) 356-383.

Choi, S.J., A.C. Pritchard, and A.C. Wiechman. Scandal Enforcement at the SEC: Salience and the Arc of the Option Backdating Investigations, Working Paper, NYU and University of Michigan (2012).

Cox, J.D., R.S. Thomas, and D. Kiku, Public and Private Enforcement of Securities Laws: Have Things Changed Since Enron? Notre Dame Law Review 80 (2004) 893-908.

Dechow, P., A. Hutton, and R. Sloan. Causes and Consequences of Earnings Manipulation: An Analysis of Firms Subject to Enforcement Actions by the SEC. Contemporary Accounting Research 13 (1996), 1-36.

DuCharme, L.L., P.H. Malatesta, and S.E. Sefcik. Earnings Management, Stock Issues, and Shareholder Lawsuits. Journal of Financial Economics 71 (2004), 27-49.

Dyck, A., A. Morse, L. Zingales. Who Blows the Whistle on Corporate Fraud? Journal of Finance 65 (2010) 2213-2253.

Feroz, E. H., K. Park, and V. S. Pastena. The Financial and Market Effects of the SEC's Accounting and Auditing Enforcement Releases. Journal of Accounting Research 29 (Supp.) (1991), 107-148.

Fich, E. and A. Shivdasani. Financial Fraud, Director Reputation, and Shareholder Wealth. Journal of Financial Economics, 2007.

Gerety, M. and K. Lehn. The Causes and Consequences of Accounting Fraud. Managerial and Decision Economics 18 (1997), 587-599. 


\section{SEC v. Class Actions}

Griffin, P.A. A League of Their Own? Financial Analysts' Responses to Restatements and Corrective Disclosures, Journal of Accounting, Auditing and Finance 18 (2003) 479- .

Griffin, Paul A., J.A. Grundfest and M. A. Perino, Stock Price Response to News of Securities Fraud Litigation: An Analysis of Sequential and Conditional Information, Abacus 40 (2004), 21-48.

Griffin, P.A. and Y. Sun, Troublesome Tidings? Investors' Response to a Wells Notice. Working Paper, UC-Davis (2011).

Hegde, S.P., C.B. Malone, and J.D. Finnerty, Fraud and Firm Performance: Evidence from Fraud on the Market and Securities Class Action Lawsuits, Working Paper: Fordham University (2010).

Helland, E. Reputational Penalties and the Merits of Class Action Securities Litigation, Journal of Law \& Economics 49 (2006), 365-396.

Humphery-Jenner, M.L. Internal and External Discipline Following Securities Class Actions, Journal of Financial Intermediation, 21 (2012) 151-179.

Karpoff, J., D.S. Lee and G.S. Martin. The Cost to Firms of Cooking the Books, Journal of Financial and Quantitative Analysis, 43 (2008a), 581-612.

Karpoff, J., D.S. Lee and G.S. Martin. The Consequences to Managers for Financial Misrepresentation, Journal of Financial Economics, 88 (2008b), 193-215.

Karpoff, J. M. and J. R. Lott, Jr. The Reputational Penalty Firms Bear from Committing Criminal Fraud. Journal of Law and Economics 36 (1993), 757-802.

Karpoff, J., D.S. Lee and G.S. Martin. The Legal Penalties for Financial Misrepresentation (2007) (Working Paper: University of Washington)

Kinney, W. and L.S. McDaniel, Characteristics of Firms Correcting Previously Reported Quarterly Earnings. Journal of Accounting \& Economics 11 (1989), 71-93.

Marciukaityte, D., S.H. Szewczyk, H. Uzun, and R. Varma, Governance and Performance Changes after Accusations of Corporate Fraud, Financial Analysts Journal (2006) 32-

Murphy, D.L., R.E. Shrieves, and S.L. Tibbs, Understanding the Penalties Associated with Corporate Misconduct: An Empirical Examination of Earnings and Risk, Journal of Financial and Quantitative Analysis 44 (2009) 55-83.

Nelson, C., S. Gilley, and G. Trombley, Disclosures of SEC investigations resulting in Wells notices. Securities Litigation Journal 19 (2009), 19-20. 


\section{SEC v. Class Actions}

Niehaus, G. and G. Roth. Insider Trading, Equity Issues, and CEO Turnover in Firms Subject to Securities Class Action. Financial Management 28 (1999), 52-72.

Palmrose, Z-V., V.J. Richardson, and S. Scholz. Determinants of Market Reactions to Restatement Announcements. Journal of Accounting \& Economics 37 (2004), 59-89.

Rose, A. Reforming Securities Litigation Reform: Restructuring the Relationship Between Public and Private Enforcement of Rule 10b-5. Columbia Law Review 108 (2008), 13011364. 
Table 1: Descriptive Statistics

By Year

\begin{tabular}{|l|c|c|c|}
\hline & SEC & Both & $\begin{array}{c}\text { Class } \\
\text { Action }\end{array}$ \\
\hline 2004 & 122 & 88 & 142 \\
\hline 2005 & 113 & 62 & 106 \\
\hline 2006 & 149 & 61 & 58 \\
\hline 2007 & 80 & 24 & 132 \\
\hline Total & 464 & 235 & 438 \\
\hline
\end{tabular}

\section{Mean (Median)}

\begin{tabular}{|l|c|c|c|c|c|c|}
\hline & SEC & $\begin{array}{c}\text { Std. } \\
\text { Dev. }\end{array}$ & Both & $\begin{array}{c}\text { Std. } \\
\text { Dev. }\end{array}$ & $\begin{array}{c}\text { Class } \\
\text { Action }\end{array}$ & $\begin{array}{c}\text { Std. } \\
\text { Dev. }\end{array}$ \\
\hline Accounting & 0.174 & - & 0.154 & - & 0.221 & - \\
\hline Restatement & 0.328 & - & 0.541 & - & 0.230 & - \\
\hline Market Cap. & $\begin{array}{c}13542.6 \\
(1527.8)\end{array}$ & 39225.3 & $\begin{array}{c}12709.1 \\
(1393.9)\end{array}$ & 32084.1 & $\begin{array}{c}9393.7 \\
(764.8)\end{array}$ & 30883.6 \\
\hline Adj. Return & $\begin{array}{c}0.109 \\
(-0.002)\end{array}$ & 0.902 & $\begin{array}{c}0.039 \\
(-0.102)\end{array}$ & 0.794 & $\begin{array}{c}-0.013 \\
(-0.148)\end{array}$ & 0.830 \\
\hline
\end{tabular}

Descriptive statistics are all measured prior to first public disclosure leading to the investigation or lawsuit. 
Table 2: Event Studies

\begin{tabular}{|c|c|c|c|c|c|c|c|c|}
\hline & \multicolumn{4}{|c|}{ Violation Date } & \multicolumn{4}{|c|}{ Action Date } \\
\hline & $\mathrm{N}$ & -1 to +1 & $\begin{array}{l}\text { Positive: } \\
\text { Negative }\end{array}$ & Patell Z & $\mathbf{N}$ & -1 to +1 & $\begin{array}{l}\text { Positive: } \\
\text { Negative }\end{array}$ & Patell Z \\
\hline SEC & 332 & $-2.09 \%$ & $129: 203<<<$ & $-7.428^{* * *}$ & 333 & $-1.80 \%$ & $122: 211<<<$ & $-7.285^{* * *}$ \\
\hline Both & 229 & $-12.73 \%$ & $35: 194<<<$ & $-45.248^{* * *}$ & 221 & $-4.83 \%$ & $64: 157<<<$ & $-18.558^{* * *}$ \\
\hline $\begin{array}{l}\text { Class } \\
\text { Action }\end{array}$ & 374 & $-21.90 \%$ & $34: 340<<<$ & $-91.715^{* * *}$ & 366 & $-2.23 \%$ & $169: 197<<<$ & $-7.990^{* * *}$ \\
\hline
\end{tabular}


Table 3: Changes in Holdings by Institutional Investors

Panel A: Descriptive Statistics

\begin{tabular}{|l|c|c|c|c|}
\hline & \multicolumn{2}{|c|}{ Violation Date } & \multicolumn{2}{c|}{ Action Date } \\
\hline & Mean & $\mathrm{p}$-value & Mean & $\mathrm{p}$-value \\
\hline Both & -0.017 & - & -0.010 & - \\
\hline SEC & 0.050 & 0.001 & 0.050 & 0.003 \\
\hline Class Action & 0.004 & 0.358 & 0.004 & 0.548 \\
\hline
\end{tabular}

Change is $-4 Q$ to $+4 Q$ around each date. $p$-value is from t-test of difference of means between SEC and either Both or Class Action respectively.

Panel B: Regression Analysis

\begin{tabular}{lcc}
\hline & $(1)$ & $(2)$ \\
& $\begin{array}{c}\text { Institutional Change } \\
\text { Violation Date }\end{array}$ & $\begin{array}{c}\text { Institutional Change } \\
\text { Action Date }\end{array}$ \\
\hline SEC & $0.0716^{* *}$ & $0.0581^{*}$ \\
& $(3.08)$ & $(2.52)$ \\
Class Action & 0.0240 & 0.0101 \\
& $(1.02)$ & $(0.42)$ \\
Accounting & -0.0186 & -0.0222 \\
& $(-0.72)$ & $(-0.82)$ \\
Restatement & $-0.0590^{* *}$ & $-0.0642^{* *}$ \\
& $(-2.80)$ & $(-3.03)$ \\
Market Cap. & $0.0125^{* *}$ & $0.0098^{*}$ \\
& $(3.25)$ & $(2.52)$ \\
Adj. Ret. & & \\
& $0.0340^{*}$ & $0.0450^{* *}$ \\
Constant & $(2.34)$ & $(3.34)$ \\
& & \\
\hline Industry Controls & 0.0385 & -0.0245 \\
\hline Year Dummies & $(0.48)$ & $(-0.44)$ \\
\hline$N$ & Yes & Yes \\
adj. $R^{2}$ & 584 & Yes \\
\hline$t$ statistics in parentheses; ${ }^{*} p<0.10,{ }^{*} p<0.05,{ }^{* *} p<0.01$. Ordinary least squares regression with robust \\
standard errors. & & 0.061 \\
& &
\end{tabular}




\section{SEC v. Class Actions}

\section{Table 4: Change in Earnings Per Share Forecast Dispersion}

Panel A: Descriptive Statistics

\begin{tabular}{|l|c|c|c|c|}
\hline & \multicolumn{2}{|c|}{ Violation Date } & \multicolumn{2}{c|}{ Action Date } \\
\hline & Mean & p-value & Mean & p-value \\
\hline Both & 0.546 & - & 0.554 & - \\
\hline SEC & 0.021 & 0.079 & 0.025 & 0.082 \\
\hline Class Action & 0.054 & 0.163 & 0.033 & 0.137 \\
\hline
\end{tabular}

Change is measured from -1 year to +1 year around each date. p-value is from t-test of difference of means between SEC and either Both or Class Action respectively.

Panel B: Regression Analysis

\begin{tabular}{|c|c|c|}
\hline & $\begin{array}{c}\text { (1) } \\
\text { EPS Change } \\
\text { Violation Date }\end{array}$ & $\begin{array}{c}(2) \\
\text { EPS Change } \\
\text { Action Date } \\
\end{array}$ \\
\hline SEC & $\begin{array}{l}-0.359^{+} \\
(-1.83)\end{array}$ & $\begin{array}{l}-0.330^{+} \\
(-1.73)\end{array}$ \\
\hline Class Action & $\begin{array}{l}-0.559^{+} \\
(-1.71)\end{array}$ & $\begin{array}{l}-0.463^{+} \\
(-1.66)\end{array}$ \\
\hline Accounting & $\begin{array}{c}0.0686 \\
(0.45)\end{array}$ & $\begin{array}{c}0.0159 \\
(0.11)\end{array}$ \\
\hline Restatement & $\begin{array}{c}0.191 \\
(0.77)\end{array}$ & $\begin{array}{l}0.0275 \\
(0.34)\end{array}$ \\
\hline Number Analysts & $\begin{array}{c}0.00318 \\
(0.70)\end{array}$ & $\begin{array}{c}0.00590 \\
(1.36)\end{array}$ \\
\hline Constant & $\begin{array}{l}4.559 \\
(1.33)\end{array}$ & $\begin{array}{l}0.184 \\
(0.62)\end{array}$ \\
\hline Industry Controls & Yes & Yes \\
\hline $\begin{array}{l}N \\
\text { adj. } R^{2}\end{array}$ & $\begin{array}{c}132 \\
0.288\end{array}$ & $\begin{array}{c}134 \\
0.422\end{array}$ \\
\hline
\end{tabular}




\section{SEC v. Class Actions}

Table 5: Turnover Change

Panel A: Descriptive Statistics

\begin{tabular}{|l|c|c|c|c|}
\hline & \multicolumn{2}{|c|}{ Violation Date } & \multicolumn{2}{c|}{ Action Date } \\
\hline & Mean & p-value & Mean & p-value \\
\hline Both & 0.034 & - & -0.015 & - \\
\hline SEC & 0.006 & 0.033 & 0.006 & 0.091 \\
\hline Class Action & -0.032 & 0.000 & -0.031 & 0.276 \\
\hline
\end{tabular}

Change is measured as the difference in the turnover for the two time periods from -130 days to -40 days and +40 to +130 around each date. $p$-value is from t-test of difference of means between SEC and either Both or Class Action respectively.

Panel B: Regression Analysis

\begin{tabular}{|c|c|c|}
\hline & $\begin{array}{c}\text { (1) } \\
\text { Turnover } \\
\text { Change } \\
\text { Violation } \\
\text { Date }\end{array}$ & $\begin{array}{c}\text { (2) } \\
\text { Turnover } \\
\text { Change } \\
\text { Action } \\
\text { Date }\end{array}$ \\
\hline SEC & $\begin{array}{c}-0.0243 \\
(-1.54)\end{array}$ & $\begin{array}{c}0.0304^{+} \\
(1.96)\end{array}$ \\
\hline Class Action & $\begin{array}{c}-0.0638^{* *} \\
(-3.52)\end{array}$ & $\begin{array}{c}-0.0064 \\
(-0.35)\end{array}$ \\
\hline Accounting & $\begin{array}{c}0.0189 \\
(1.11)\end{array}$ & $\begin{array}{l}0.0050 \\
(0.30)\end{array}$ \\
\hline Restatement & $\begin{array}{l}0.0120 \\
(0.85)\end{array}$ & $\begin{array}{c}0.0259^{+} \\
(1.83)\end{array}$ \\
\hline Market Cap. & $\begin{array}{c}0.0088^{* *} \\
(2.74)\end{array}$ & $\begin{array}{c}0.0118^{* *} \\
(3.72)\end{array}$ \\
\hline Inst. Ownership (Post) & $\begin{array}{l}-0.0195 \\
(-1.40)\end{array}$ & $\begin{array}{c}-0.0147 \\
(-1.21)\end{array}$ \\
\hline Constant & $\begin{array}{c}-0.0746 \\
(-0.55)\end{array}$ & $\begin{array}{c}-0.123^{* *} \\
(-3.16)\end{array}$ \\
\hline Industry Controls & Yes & Yes \\
\hline $\begin{array}{l}N \\
\text { adj. } R^{2}\end{array}$ & $\begin{array}{c}687 \\
0.043\end{array}$ & $\begin{array}{c}680 \\
0.048\end{array}$ \\
\hline
\end{tabular}


Law \& Economics W orking Papers, Art. 55 [2012]

SEC v. Class Actions

Table 6: Change in Residual Bid-Ask Spread

Panel A: Descriptive Statistics

\begin{tabular}{|l|c|c|c|c|}
\hline & \multicolumn{2}{|c|}{ Violation Date } & \multicolumn{2}{c|}{ Action Date } \\
\hline & $\begin{array}{c}\text { Difference in } \\
\text { Pre-Post Means }\end{array}$ & p-value & $\begin{array}{c}\text { Difference in } \\
\text { Pre-Post Means }\end{array}$ & $\mathrm{p}$-value \\
\hline Both & -0.002 & - & -0.004 & - \\
\hline SEC & -0.001 & 0.805 & -0.001 & 0.248 \\
\hline Class Action & -0.001 & 0.906 & -0.002 & 0.331 \\
\hline
\end{tabular}

Change is measured as the difference in the residual bid-ask spread for the two time periods from -130 days to -40 days and +40 to +130 around each date. $p$-value is from t-test of difference of means between SEC and either Both or Class Action respectively.

Panel B:

\begin{tabular}{|c|c|c|}
\hline & $\begin{array}{c}\text { Model } 1 \\
\text { Difference in } \\
\text { Residual Bid-Ask } \\
\text { Spread } \\
\text { Violation Date }\end{array}$ & $\begin{array}{c}\text { Model } 2 \\
\text { Difference in } \\
\text { Residual Bid-Ask } \\
\text { Spread } \\
\text { Action Date }\end{array}$ \\
\hline SEC & $\begin{array}{c}-0.0003 \\
(-0.14)\end{array}$ & $\begin{array}{c}0.0034 \\
(1.00)\end{array}$ \\
\hline Class Action & $\begin{array}{c}0.0020 \\
(0.80)\end{array}$ & $\begin{array}{c}0.0051 \\
(1.57)\end{array}$ \\
\hline Accounting & $\begin{array}{c}-0.0010 \\
(-0.44)\end{array}$ & $\begin{array}{c}-0.0000 \\
(-0.01)\end{array}$ \\
\hline Restatement & $\begin{array}{c}0.0037^{+} \\
(1.66)\end{array}$ & $\begin{array}{c}0.0057^{*} \\
(2.48)\end{array}$ \\
\hline Market Cap. & $\begin{array}{c}0.166^{* *} \\
(4.18)\end{array}$ & $\begin{array}{c}0.188^{* *} \\
(3.93)\end{array}$ \\
\hline Constant & $\begin{array}{c}-1.608^{* *} \\
(-4.16)\end{array}$ & $\begin{array}{c}-1.839^{* *} \\
(-3.95)\end{array}$ \\
\hline Industry Controls & & Yes \\
\hline $\begin{array}{l}N \\
\text { Pseudo } R^{2}\end{array}$ & $\begin{array}{c}377 \\
0.088 \\
\end{array}$ & $\begin{array}{c}300 \\
0.095\end{array}$ \\
\hline
\end{tabular}

$z$ statistics in parentheses; ${ }^{+} p<0.10,{ }^{*} p<0.05,{ }^{* *} p<0.01$. Dependent variable is the difference in the average daily residual bid-ask spread for the time period from -130 to -40 relative to the date in question (Violation or Action Date) compared with the time period from +40 to +130 calendar days centered on the date in question. t-statistics are based on robust standard errors. 
Choi and Pritchard:

\section{SEC v. Class Actions}

Table 7: Settlements

Panel A: $\quad$ Descriptive Statistics

\begin{tabular}{|l|c|c|c|c|c|c|}
\hline & \multicolumn{3}{|c|}{ Incidence } & \multicolumn{3}{c|}{ Monetary Penalty } \\
\hline & SEC & Both & p-value & SEC & Both & p-value \\
\hline SEC Settlement & 0.213 & 0.404 & 0.000 & 12.6 & 13.1 & 0.926 \\
\hline Class Action Settlement & 0.429 & 0.579 & 0.007 & 14.9 & 52.4 & 0.000 \\
\hline
\end{tabular}

Monetary penalty is in millions of dollars. Mean p-value is from t-test of difference of means between SEC and either Both or Class Action as indicated above.

Panel B: Logit Model of Settlement Likelihood

\begin{tabular}{|c|c|c|c|}
\hline & $\begin{array}{l}\text { Model 1: } \\
\text { SEC Settle }\end{array}$ & $\begin{array}{c}\text { Model 2: } \\
\text { Class Action Settle }\end{array}$ & $\begin{array}{c}\text { Model 3: } \\
\text { Either Settle }\end{array}$ \\
\hline SEC & $\begin{array}{l}-0.613^{* *} \\
(-3.09)\end{array}$ & & $\begin{array}{l}-1.844^{* *} \\
(-9.21)\end{array}$ \\
\hline Class Action & & $\begin{array}{l}-0.450^{*} \\
(-2.24)\end{array}$ & $\begin{array}{l}-1.072^{* *} \\
(-5.47)\end{array}$ \\
\hline Accounting & $\begin{array}{l}-0.885^{* *} \\
(-2.68)\end{array}$ & $\begin{array}{l}0.410 \\
(1.62)\end{array}$ & $\begin{array}{c}-0.0933 \\
(-0.46)\end{array}$ \\
\hline Restatement & $\begin{array}{c}0.0528 \\
(0.23)\end{array}$ & $\begin{array}{l}0.934^{* *} \\
(4.34)\end{array}$ & $\begin{array}{l}0.329^{+} \\
(1.89)\end{array}$ \\
\hline Market Cap. & $\begin{array}{l}0.123^{*} \\
(2.43)\end{array}$ & $\begin{array}{l}-0.235^{* *} \\
(-4.78)\end{array}$ & $\begin{array}{c}-0.0986^{* *} \\
(-2.62)\end{array}$ \\
\hline Constant & $\begin{array}{l}-1.317^{*} \\
(-2.06)\end{array}$ & $\begin{array}{l}1.976^{* *} \\
(3.14)\end{array}$ & $\begin{array}{l}1.173^{*} \\
(2.45)\end{array}$ \\
\hline Industry Controls & Yes & Yes & Yes \\
\hline $\begin{array}{l}N \\
\text { pseudo } R^{2}\end{array}$ & $\begin{array}{c}535 \\
0.049\end{array}$ & $\begin{array}{c}556 \\
0.087\end{array}$ & $\begin{array}{c}884 \\
0.101\end{array}$ \\
\hline
\end{tabular}


Law \& Economics W orking Papers, Art. 55 [2012]

SEC v. Class Actions

Panel C: OLS Model of Monetary Penalty

\begin{tabular}{lccc}
\hline & $\begin{array}{c}\text { Model 1 } \\
\ln (\text { SEC Total } \\
\text { Monetary Penalty) }\end{array}$ & $\begin{array}{c}\text { Model 2 } \\
\text { in(Class Action } \\
\text { Settlement) }\end{array}$ & $\begin{array}{c}\text { Model 3 } \\
\text { ln(Aggregate } \\
\text { Sanction) }\end{array}$ \\
\hline SEC & 0.307 & & $-0.860^{* *}$ \\
& $(1.25)$ & & $(-3.87)$ \\
Class Action & & $-0.400^{* *}$ & -0.180 \\
& & $(-3.14)$ & $(-1.18)$ \\
Accounting & $-1.425^{* *}$ & $0.359^{*}$ & -0.0286 \\
& $(-3.99)$ & $(2.02)$ & $(-0.14)$ \\
Restatement & $-0.667^{*}$ & $0.542^{* *}$ & $0.279^{+}$ \\
& $(-2.08)$ & $(4.11)$ & $(1.70)$ \\
Market Cap. & $0.180^{* *}$ & $0.379^{* *}$ & $0.265^{* *}$ \\
& $(2.68)$ & $(8.01)$ & $6.03)$ \\
Constant & 0.535 & -0.342 & 0.590 \\
& $(0.56)$ & $(-0.97)$ & $(1.31)$ \\
\hline Industry Controls & Yes & Yes & Yes \\
\hline$N$ & 172 & 258 & 375 \\
adj. $R^{2}$ & 0.175 & 0.451 & 0.178 \\
\hline
\end{tabular}

$t$ statistics in parentheses; ${ }^{+} p<0.10,{ }^{*} p<0.05,{ }^{* *} p<0.01$. Model 1 is estimated only on the SEC and Both samples. Model 2 is estimated only on the Class Action and Both samples. Model 3 is estimated on the SEC, Class Action, and Both samples. All models are estimated only where there is a SEC or Class Action settlement. 


\section{SEC v. Class Actions}

Table 8: Officer Resignations

Panel A: Descriptive Statistics

\begin{tabular}{|l|c|c|}
\hline & \multicolumn{2}{|c|}{ Officer Resign } \\
\hline & Mean & $\mathrm{p}$-value \\
\hline Both & 0.513 & - \\
\hline SEC & 0.326 & 0.000 \\
\hline Class Action & 0.348 & 0.000 \\
\hline
\end{tabular}

p-value is from t-test of difference of means between SEC and either Both or Class Action respectively.

\section{Panel B: Logit Model of Officer Resignation Likelihood} Model 1 Officer Resignation

\begin{tabular}{lc} 
& Officer Resignation \\
\hline SEC & $-0.951^{* *}$ \\
& $(-4.32)$ \\
& $-0.434^{+}$ \\
Class Action & $(-1.95)$ \\
& -0.121 \\
& $(-0.46)$ \\
Accounting & $1.438^{* *}$ \\
& $(7.30)$ \\
Restatement & $-0.138^{* *}$ \\
& $(-2.98)$ \\
Market Cap. & -0.061 \\
& $(-0.62)$ \\
Adj. Ret. & 0.314 \\
& $(0.58)$ \\
Constant & Yes \\
& 746 \\
\hline Industry Controls & 0.149 \\
\hline$N$ & \\
Pseudo $R^{2}$ &
\end{tabular}


SEC v. Class Actions

Table 9: Descriptive Statistics

By Year

\begin{tabular}{|l|c|c|c|c|c|c|}
\hline & $\begin{array}{c}\text { SEC } \\
\text { (Formal) }\end{array}$ & $\begin{array}{c}\text { \% of } \\
\text { SEC }\end{array}$ & $\begin{array}{c}\text { Both } \\
\text { (Formal + } \\
\text { Survive } \\
\text { MTD) }\end{array}$ & $\begin{array}{c}\text { \% of } \\
\text { Both }\end{array}$ & $\begin{array}{c}\text { Class } \\
\text { Action } \\
\text { (Survive } \\
\text { MTD) }\end{array}$ & $\begin{array}{c}\text { \% of } \\
\text { Class } \\
\text { Action }\end{array}$ \\
\hline 2004 & 42 & $34.4 \%$ & 16 & $18.2 \%$ & 77 & $54.2 \%$ \\
\hline 2005 & 42 & $37.2 \%$ & 26 & $41.9 \%$ & 46 & $43.4 \%$ \\
\hline 2006 & 49 & $32.9 \%$ & 28 & $45.9 \%$ & 26 & $44.8 \%$ \\
\hline 2007 & 31 & $38.8 \%$ & 13 & $54.2 \%$ & 75 & $56.8 \%$ \\
\hline Total & 164 & $35.3 \%$ & 83 & $35.3 \%$ & 224 & $51.1 \%$ \\
\hline
\end{tabular}

Mean (Median)

\begin{tabular}{|l|c|c|c|c|c|c|}
\hline & $\begin{array}{c}\text { SEC } \\
\text { (Formal) }\end{array}$ & $\begin{array}{c}\text { Std. } \\
\text { Dev. }\end{array}$ & $\begin{array}{c}\text { Both } \\
\text { (Formal + } \\
\text { Survive } \\
\text { MTD) }\end{array}$ & $\begin{array}{c}\text { Std. } \\
\text { Dev. }\end{array}$ & $\begin{array}{c}\text { Class } \\
\text { Action } \\
\text { (Survive } \\
\text { MTD) }\end{array}$ & $\begin{array}{c}\text { Std. } \\
\text { Dev. }\end{array}$ \\
\hline Accounting & 0.099 & - & 0.120 & - & 0.248 & - \\
\hline Restatement & 0.317 & - & 0.707 & - & 0.284 & - \\
\hline Market Cap. & 20516.8 & 55543.9 & $\begin{array}{c}8754.3 \\
(1153.8)\end{array}$ & 21920.0 & 8835.5 & 32323.3 \\
& $(2187.9)$ & 1.002 & $\begin{array}{c}0.070 \\
(-0.119)\end{array}$ & 0.957 & -0.063 & 0.935 \\
\hline Adj. Return & $\begin{array}{c}0.088 \\
(-0.023)\end{array}$ & $1-0.217)$ & \\
\hline
\end{tabular}

Descriptive statistics are all measured prior to first public disclosure leading to the investigation or lawsuit. 


\section{SEC v. Class Actions}

\section{Appendix: Variable Definitions}

Key Independent Variables

Variable

Accounting

Restatement

Market Cap.

\section{Definition}

Indicator variable equal to one if accounting issues not involving a restatement are related to the SEC investigation and/or Class Action suit.

Indicator variable equal to one if the firm restated earnings that are related to the SEC investigation and/or Class Action suit.

Log of market value of common equity for the issuer in question at the end of calendar year preceding the commencement of the SEC investigation (or if there was no SEC investigation, the Class Action filing)

Adjusted Return The one-year return up to 1 week prior to first public disclosure date for the issuer in question, adjusted by the value weighted CRSP index return for the same period.

Number Analysts Number of analysts that follow the issuer in question measured for the year after the year of the Violation date. 